\title{
Botulinum toxin for treating muscular temporomandibular disorders: A systematic review
}

\author{
Eduardo Machado', Lívia Zuchetto dos Santos², Lilian Gonçalves Custódio³, Paulo Afonso Cunali
}

\begin{abstract}
Objective: This study, through a systematic literature review, aims to analyze the effectiveness of Botulinum Toxin as a treatment for masticatory myofascial pain and muscles temporomandibular disorders (TMD). Methods: Survey in research bases: MEDLINE, Cochrane, EMBASE, Pubmed, Lilacs and BBO, between the years of 1966 and April 2011, with focus in randomized or quasi-randomized controlled clinical trials, blind or double-blind. Results: After applying the inclusion criteria, 4 articles comprised the final sample: 3 were double-blind randomized controlled clinical trials and 1 was single-blind randomized controlled clinical trial. Conclusions: According to the literature, there is lack of evidence about the real effectiveness of botulinum toxin in the treatment of masticatory myofascial pain and muscular TMD. Thus, further randomized controlled clinical trials, with representative samples and longer follow-up time, to assess the real effectiveness of the technique are needed.
\end{abstract}

Keywords: Botulinum toxins type A. Botulinum toxins. Temporomandibular joint dysfunction syndrome. Temporomandibular joint disorders. Myofascial pain syndromes.

Objetivo: este trabalho, por meio de uma revisão sistemática da literatura, teve como objetivo analisar a efetividade da toxina botulínica como tratamento para dor miofascial mastigatória e disfunções temporomandibulares (DTM) musculares. Métodos: pesquisa nas bases de dados Medline, Cochrane, Embase, Pubmed, Lilacs e BBO, no período entre 1966 e abril de 2011, com enfoque em estudos clínicos controlados randomizados ou quase-randomizados, cegos ou duplo-cegos. Resultados: após a aplicação dos critérios de inclusão, chegou-se a 4 artigos, sendo que 3 eram estudos clínicos controlados randomizados duplo-cego e 1 era estudo clínico controlado randomizado simples-cego. Conclusões: pela análise da literatura, verificou-se um número reduzido de evidências significativas sobre a real efetividade da toxina botulínica no tratamento da dor miofascial e de DTM musculares. Assim, são necessários novos estudos clínicos controlados randomizados, com amostras representativas e tempo de acompanhamento longo, para avaliar a real efetividade da técnica.

Palavras-chave: Toxinas botulínicas tipo A. Toxinas botulínicas. Síndrome da disfunção da articulação temporomandibular. Transtornos da articulação temporomandibular. Síndromes da dor miofascial.

${ }^{1}$ Specialist in TMD and Orofacial Pain, UFPR.

${ }^{2}$ Student, Specialization Course in Prosthodontics, ABORS.

${ }^{3}$ Specialist in TMD and Orofacial Pain, UFPR and Professor of Undergraduate and Graduate Dental Courses, UFPR.

${ }^{4} \mathrm{PhD}$, UNIFESP and Professor of Undergraduate and Graduate Dental Courses, UFPR. Head of the Specialization Course in TMD and Orofacial Pain, UFPR.

\author{
How to cite this article: Machado E, Santos LZ, Custódio LG, Cunali PA. Botulinum \\ toxin for treating muscular temporomandibular disorders: A systematic review. Den- \\ tal Press J Orthod. 2012 Nov-Dec;17(6):167-71. \\ Submitted: June 20, 2011 - Revised and accepted: February 5, 2012 \\ " The author reports no commercial, proprietary or financial interest in the products \\ or companies described in this article. \\ Contact address: Eduardo Machado \\ Rua Francisco Trevisan, 20, Nossa Sra. de Lourdes - Santa Maria/RS - Brazil \\ CEP: 97050-230 - E-mail: dr.eduardomachado@yahoo.com.br
}




\section{INTRODUCTION}

Temporomandibular disorders (TMD) are considered a subgroup of musculoskeletal and rheumatologic disorders, and represent the main cause of non-dental pain in the orofacial region. ${ }^{1}$ Due to the great complexity and variety of etiological signs and symptoms of TMD, which may generally also represent other diseases, the diagnosis is not always clear to the professional, ${ }^{2}$ requiring precise clinical diagnostic criteria, and when necessary, evaluations of imaging examinations such as computed tomography, magnetic resonance imaging and X-rays for a correct diagnosis.

In this context, myofascial pain is part of muscular TMD, and its diagnosis and treatment is a constant challenge for the professional. The initial therapeutic options should be minimally invasive, reversible and conservative. We can cite as alternative treatment oral appliances, jaw exercises, drugs, laser, cooling followed by stretching of the affected muscle, infiltration of trigger points with local anesthetics or dry needling, among other therapies. ${ }^{1}$ Some patients may not be responsive to the treatments described above, and botulinum toxin in this situation may appear as an alternative due to its analgesic and antinociceptive properties. This neurotoxin is produced by bacteria called Clostridium botulinium on seven different types, which are designated by letters A, B, C, D, E, F and G, and the botulinum toxin type $\mathrm{A}$ is more widely used. ${ }^{3}$

Botulinum toxin has been used since 1977 in the treatment of several neuromuscular disorders, ${ }^{3,4}$ such as oromandibular dystonia. ${ }^{5,6}$ Its action is based on blocking the release of acetylcholine at presynaptic nerve endings in neuromuscular junctions, making its action non-functional and inhibiting muscular contraction. ${ }^{7}$ The clinical effects appear between one and three days after administration of botulinum toxin, and the maximum effects occur after one to two weeks, which then stabilizes to a moderate level until complete recovery of the nerve in approximately three months. ${ }^{3}$

Thus, the infiltration of trigger points with botulinum toxin type A (BTX-A) or its use in other situations of muscular TMD, such as muscle hyperactivity associated with Sleep Bruxism (SB), appears as an alternative treatment in patients non-respon- dant to conventional treatments. This way, the aim of this study, through a systematic literature review, was to analyze within a context of scientific evidence based Dentistry, the effectiveness of botulinum toxin as treatment for masticatory myofascial pain and muscular TMD.

\section{MATERIAL AND METHODS}

We performed a computerized search in MEDLINE, Cochrane, EMBASE, Pubmed, Lilacs and BBO in the period from 1966 to April 2011. The date of 1966 was used because it is the period in which the initial articles consultation and the research descriptors involved terms widely used within the line of research proposed by this study appear on Medline. The descriptors used were "botulinum toxin", "botulinum toxin type A", "temporomandibular disorder", "temporomandibular joint", "craniomandibular disorder", "myofascial pain" and "TMD", which were crossed in search engines. The initial list of studies were assessed by their title and abstract, and were subjected to review by two reviewers, who applied inclusion criteria to determine the final sample of articles. If there was any disagreement between the results of the reviewers, a third appraiser would be found by reading the full version of the article and the rate of agreement between reviewers was assessed using the Kappa index.

Inclusion criteria for selecting articles were:

» Studies in which, specifically, the effectiveness of botulinum toxin were evaluated for the treatment of muscle temporomandibular disorders (TMD) - with focus on masticatory myofascial pain and muscle hyperactivity.

» Studies in which botulinum toxin was compared to no treatment, placebo, oral appliances, pharmacological therapies, infiltrations of trigger points with other substances or dry needling, laser, acupuncture and relaxation and physical therapies associated or not with cryotherapy.

» Diagnostic criteria for TMD based on clinical examinations and/or imaging from computed tomography (CT) or nuclear magnetic resonance imaging (MRI).

" Controlled randomized clinical trials (RCTs) or quasi-randomized, double or single-blind. 
» No restriction on languages and studies published between 1966 and April 2011.

Thus, we excluded cross-sectional studies, case series, case reports and authors opinions, within the context of an evidence-based Dentistry.

\section{RESULTS}

The initial list of articles presented 212 possible studies, which after applying the inclusion criteria by this systematic review was reduced to four studies that met all the inclusion criteria: Three doubleblind randomized controlled clinical trials and one single-blind. There was no disagreement between reviewers in the final selection of articles, with no need of using a third reviewer and the Kappa index of agreement between reviewers was 1.00.

Table 1 presents the results of selected studies.

\section{DISCUSSION}

Increasingly inserted within a context of scientific evidence based Dentistry, discussion of current evidences must be guided in a critical and rigorous way. The availability of universal access to journals and magazines brings the need for knowledge by the reader of the scientific article about study designs and methodological criteria related to higher levels of scientific evidence. Thus, studies with longitudinal nature associated with methodological criteria such as randomization, sample size calculation, blinding, calibration, control of factors, among others, cause a qualification of evidence generated by the study and therefore a scientific information with major precise and impact. ${ }^{12}$

The antinociceptive and analgesic properties of botulinum toxin A are much discussed in the literature. It is suggested that the BTX-A generates analgesic benefits in the treatment of neuromuscular disorders - particularly focal dystonias and spasmodic conditions, ${ }^{13}$ in which involuntary muscles movements occur, that can affect various regions of the body. Initially it is believed that this benefit is associated with muscle relaxation provided by the infiltration with BTX-A, but several considerations have suggested that the BTX-A can play an independent role in peripheral nociceptors by blocking the release of certain neurotransmitters like substance $\mathrm{P}$, glutamate and calcitonin gene-related peptide (CGRP). ${ }^{14}$

The biological plausibility to evaluate the effectiveness of botulinum toxin in pain control was firstly analyzed in animal studies. In a model involving rats, the authors evaluated the effects of botulinum toxin on the nerve fibers of the bladder. The filling up of the bladder was performed with acetic acid $0.3 \%$ and it was found that rats previously treated with BTX-A showed a significant decrease of CGRP release after 7 days of injection when compared to control. ${ }^{15}$ Another study examined the injection of formalin in the rat paw, which causes the release of glutamate, and obtained improvements in the pre-administration of botulinum toxin. ${ }^{16}$ Other evidence based on animal models also attest to the

Table 1 - Results of the included studies.

\begin{tabular}{|c|c|c|c|c|c|}
\hline $\begin{array}{l}\text { Authors and publication } \\
\text { (year) }\end{array}$ & $\begin{array}{l}\text { Study } \\
\text { design }\end{array}$ & $\begin{array}{c}\text { Diagnostic criteria for } \\
\text { TMD }\end{array}$ & Sample size (n) & $\begin{array}{l}\text { Evaluation } \\
\text { period }\end{array}$ & Results \\
\hline $\begin{array}{l}\text { Von Lindern et al. } \\
\qquad(2003)\end{array}$ & $\begin{array}{l}\text { single-blind and } \\
\text { controlled RCT }\end{array}$ & $\begin{array}{c}\text { Chronic facial pain } \\
\text { associated with muscle } \\
\text { hyperactivity }\end{array}$ & $\begin{array}{l}60 \text { tt BTX-A } \\
30 \text { tt PL }\end{array}$ & 4 weeks & $\begin{array}{l}\text { BTX-A effective in cases of chronic } \\
\text { facial pain associated with muscle } \\
\text { hyperactivity }\end{array}$ \\
\hline $\begin{array}{l}\text { Guarda-Nardini et al. }{ }^{9} \\
\text { (2008) }\end{array}$ & $\begin{array}{l}\text { double-blind and } \\
\text { controlled RCT }\end{array}$ & $\begin{array}{l}\text { RDC/TMD: myofascial } \\
\text { pain }\end{array}$ & $\begin{array}{l}10 \text { tt BTX-A } \\
10 \text { tt PL }\end{array}$ & 6 months & $\begin{array}{l}\text { BTX-A more effective than PL in } \\
\text { cases of myofascial pain in bruxists }\end{array}$ \\
\hline $\begin{array}{l}\text { Kurtoglu et al. }{ }^{10} \\
\qquad(2008)\end{array}$ & $\begin{array}{l}\text { double-blind and } \\
\text { controlled RCT }\end{array}$ & $\begin{array}{l}\text { RDC/TMD: myofascial } \\
\text { pain with or without DD }\end{array}$ & $\begin{array}{l}12 \text { tt BTX-A } \\
12 \text { tt PL }\end{array}$ & 28 days & $\begin{array}{l}\text { Positive effects of BTX-A in } \\
\text { situations of myofascial pain }\end{array}$ \\
\hline $\begin{array}{l}\text { Ernberg et al. }{ }^{11} \\
\qquad(2011)\end{array}$ & $\begin{array}{l}\text { double-blind, } \\
\text { placebo-controlled } \\
\text { and crossover RCT }\end{array}$ & RDC/ myofascial pain & design tt & 3 months & Effect BTXA \\
\hline
\end{tabular}

Subtitle: RCT: randomized clinical trial; RDC/TMD: Research Diagnostic Criteria for Temporomandibular Disorders; tt: Treatment; BTX-A: Botulinum toxin type A; PL: Placebo (saline solution); DD: Disc displacement. 
analgesic effects ${ }^{13,17}$ and antinociceptive properties ${ }^{18}$ of botulinum toxin.

The results of this systematic review showed that there are a small number of significant evidences that evaluate botulinum toxin in the treatment of muscles temporomandibular disorders, with a focus on myofascial pain. This fact demonstrates the need to evaluate the effectiveness of botulinum toxin through longitudinal, randomized and controlled trials, with rigorous methodological criteria. Furthermore, to assess the representativeness of the sample, the sample size calculation becomes an important tool, as well an appropriate follow-up time of the study, so that the results can be extrapolated to the general population.

It is important to analyze the degree of scientific evidence generated by this systematic review. By applying the inclusion criteria previously established, there were a very small number of articles, which limits accurate conclusions. Still, the four articles selected had methodological limitations, due to small samples ${ }^{9,10,11}$ and short follow-up time, ${ }^{8,10}$ which compromises the analysis of results and reduces the level of evidence generated. Moreover, in three selected studies the diagnostic criteria used for TMD was the RDC/TMD, ${ }^{9,10,11}$ while the other selected study used chronic facial pain related to muscle hyperactivity. ${ }^{8}$

The results of randomized clinical trials included different results. While some have satisfactory outcomes when the use of botulinum toxin, ${ }^{8,9,10}$ another has no significant clinical results regarding its use." Likewise, studies that had the longer follow-up time, three ${ }^{11}$ and six ${ }^{9}$ months, also showed different results regarding the effectiveness of botulinum toxin.

Even the findings of selected studies in this systematic review should be carefully analyzed. Even three studies showing positive results ${ }^{8,9,10}$ in relation to the use of botulinum toxin in the treatment of myofascial pain and muscles TMD, the presence of small samples ${ }^{9,10,11}$ and short follow-up time ${ }^{8,10} \mathrm{de}-$ crease the quality of evidence, reducing the generated scientific impact. This demonstrates the need to evaluate botulinum toxin on representative samples and with a long follow-up time to obtain more accurate results about its efficacy in the treatment of myofascial pain and muscles TMD.
Electromyographic evaluations were also used to evaluate the effects of botulinum toxin type A on muscle activity of patients with myofascial pain, with or without disc displacement, diagnosed by RDC/TMD. The results showed a decrease of muscle potential action of the masseter in the evaluation after 14 days and an increase in potential 28 days after the procedure. It was also found that the reduction of pain and improvement in psychological indices persisted at reassessment 28 days after the intervention. The results of this study show positive effects of BTX-A in cases of myofascial pain, but the authors call attention to the small sample evaluated. ${ }^{10}$

In treatment protocols for myofascial pain, infiltrations of trigger points with local anesthetics ${ }^{19,20}$ has been widely used or dry needling, ${ }^{19}$ with safety, effectiveness and more accessible cost that botulinum toxin. Still, double blind randomized controlled clinical trials in situations of myofascial pain syndrome in regions that are not the masticatory muscles, show different results in relation to the effects of verifying beneficial results ${ }^{21}$ and no significant clinical gain. ${ }^{22}$ Further, other RCTs in different regions of the body had results similar to bupivacaine in situations of myofascial pain syndrome, and the cost-benefit analysis pointed to the use of bupivacaine. ${ }^{23,24}$ And other forms of treatment for myofascial pain, with a cost-benefit relation more accessible for patients, and analyzed in RCTs include laser, ${ }^{25}$ acupuncture, ${ }^{26}$ ultrasound ${ }^{27}$ and jaw exercises ${ }^{28}$ with good results.

We must acknowledge that due to the multifactorial nature and great complexity of temporomandibular disorders, the first therapeutic option should always be conservative, reversible and minimally invasive. The use of botulinum toxin in the treatment of TMD, especially in myofascial pain, may be an alternative in cases refractory to conventional treatments. Thus, knowledge based on scientific evidences, associated with good clinical sense should guide the choice of the best protocol for patients with myofascial pain.

\section{CONCLUSIONS}

" Due to the limitations in the selected studies and the small number of methodologically con- 
sistent studies that proposed to evaluate the applications of botulinum toxin in cases of masticatory myofascial pain and muscular TMD, it becomes difficult to obtain precise conclusions about its real effectiveness.

» Regarding to the role of botulinum toxin in the treatment of patients with bruxism and muscle hyperactivity, evidences also are reduced and the studies have limitations, reducing the generated level of evidence.

» Further double-blind randomized controlled clinical trials, with standardized diagnostic criteria for TMD are necessary to evaluate the real effectiveness of the use of botulinum toxin as a treatment option for masticatory myofascial pain and muscle temporomandibular disorders.

\section{REFERENCES}

1. Oliveira W. Disfunções temporomandibulares. São Paulo: Artes Médicas; 2002

2. Delboni MEG, Abrão J. Estudo dos sinais de DTM em pacientes ortodônticos assintomáticos. Rev Dental Press Ortod Ortop Facial. 2005;10(4):88-96.

3. Blitzer A, Sulica L. Botulinum toxin: basic science and clinical uses in otolaryngology. Laryngoscope. 2001;111(2):218-26.

4. Yin S, Stucker FJ, Nathan CA. Clinical application of botulinum toxin in otolaryngology, head and neck practice [brief review]. J La State Med Soc. 2001;153(2):92-7.

5. Vazquez-Delgado E, Okeson JP. Treatment of inferior lateral pterygoid muscle dystonia with zolpidem tartrate, botulinum toxin injections, and physical selfregulation procedures: a case report. Cranio. 2004;22(4):325-9.

6. Balasubramaniam R, Rasmussen J, Carlson LW, Van Sickels JE, Okeson JP. Oromandibular dystonia revisited: a review and a unique case. J Oral Maxillofac Surg. 2008;66(2):379-86

7. Bentsianov B, Zalvan C, Blitzer A. Noncosmetic uses of botulinum toxin. Clin Dermatol. 2004;22(1):82-8.

8. Von Lindern JJ, Niederhagen B, Bergé S, Appel T. Type A botulinum toxin in the treatment of chronic facial pain associated with masticatory hyperactivity. J Oral Maxillofac Surg. 2003;61(7):774-8.

9. Guarda-Nardini L, Manfredini D, Salamone M, Salmaso L, Tonello S, Ferronato G. Efficacy of botulinum toxin in treating myofascial pain in bruxers: a controlled placebo pilot study. Cranio. 2008;26(2):126-35.

10. Kurtoglu C, Gur OH, Kurkcu M, Sertdemir Y, Guler-Uysal F, Uysal H. Effect of botulinum toxin-A in myofascial pain patients with or without functional disc displacement. J Oral Maxillofac Surg. 2008;66(8):1644-51.

11. Ernberg M, Hedenberg-Magnusson B, List T, Svensson P. Efficacy of botulinum toxin type $A$ for treatment of persistent myofascial TMD pain: a randomized, controlled, double-blind multicenter study. Pain. 2011;152(9):1988-96.

12. Susin C, Rosing CK. Praticando odontologia baseada em evidências. 1a ed. Canoas: ULBRA; 1999.

13. Aoki KR. Evidence for antinociceptive activity of botulinum toxin type $A$ in pain management. Headache 2003;43 Suppl 1:S9-15.

14. Dressler D, Adib Saberi F. Botulinum toxin: mechanisms of action. Eur Neurol. 2005;53(1):3-9.

15. Chuang YC, Yoshimura N, Huang CC, Chiang PH, Chancellor MB. Intravesical botulinum toxin $\mathrm{A}$ administration produces analgesia against acetic acid induced bladder pain responses in rats. J Urol. 2004;172(4 Pt 1):1529-32.

16. Cui M, Khanijou S, Rubino J, Aoki KR. Subcutaneous administration of botulinum toxin A reduces formalin-induced pain. Pain. 2004;107:125-33.
17. Durham PL, Cady R, Cady R. Regulation of calcitonin gene-related peptide secretion from trigeminal nerve cells by botulinum toxin type $A$ : implications for migraine therapy. Headache. 2004;44(1):35-43.

18. Bach-Rojecky L, Lackovic Z. Antinociceptive effect of botulinum toxin type a in rat model of carrageenan and capsaicin induced pain. Croat Med J. 2005;46(2):201-8.

19. Krishnan SK, Benzon HT, Siddiqui T, Canlas B. Pain on intramuscular injection of bupivacaine, ropivacaine, with and without dexamethasone. Reg Anesth Pain Med. 2000;25(6):615-9.

20. Zaralidou AT, Amaniti EN, Maidatsi PG, Gorgias NK, Vasilakos DF. Comparison between newer local anesthetics for myofascial pain syndrome management. Methods Find Exp Clin Pharmacol. 2007;29(5):353-7.

21. Porta M. A comparative trial of botulinum toxin type $A$ and methylprednisolone for the treatment of myofascial pain syndrome and pain from chronic muscle spasm. Pain. 2000;85(1-2):101-5.

22. Qerama E, Fuglsang-Frederiksen A, Kasch H, Bach FW, Jensen TS. A double-blind, controlled study of botulinum toxin A in chronic myofascial pain. Neurology. 2006 Jul 25;67(2):241-5.

23. Graboski CL, Gray DS, Burnham RS. Botulinum toxin A versus bupivacaine trigger point injections for the treatment of myofascial pain syndrome: a randomized double blind crossover study. Pain. 2005;118(1-2):170-5

24. De Andrés J, Adsuara VM, Palmisani S, Villanueva V, López-Alarcón MD. A double-blind, controlled, randomized trial to evaluate the efficacy of botulinum toxin for the treatment of lumbar myofascial pain in humans. Reg Anesth Pain Med. 2010;35(3):255-60

25. Ceylan Y, Hizmetli S, Silig Y. The effects of infrared laser and medical treatments on pain and serotonin degradation products in patients with myofascial pain syndrome. A controlled trial. Rheumatol Int. 2004;24(5):260-3.

26. Smith P, Mosscrop D, Davies S, Sloan P, Al-Ani Z. The efficacy of acupuncture in the treatment of temporomandibular joint myofascial pain: a randomized controlled trial. J Dent. 2007;35(3):259-67

27. Srbely JZ, Dickey JP. Randomized controlled study of the antinociceptive effect of ultrasound on trigger point sensitivity: novel applications in myofascial therapy? Clin Rehabil. 2007;21(5):411-7.

28. Michellotti A, Steenks MH, Farella M, Parisini F, Cimono R, Martina R. The additional value of a home physical therapy regimen versus patient education only for the treatment of myofascial pain of the jaw muscles: short-term results of a randomized clinical trial. J Orofac Pain. 2004;18(2):114-25. 